\title{
Comparative assessment of dried fish quality collected from market and drying centre at Kuakata in Patuakhali, Bangladesh
}

\author{
MST. NILOY JAMAN, MD. SAZEDUL HOQUE*, FARJANA YEASMIN, \\ MD. MAHMUDUL HASAN, MD. ABU SAYED RIPON, ASMA AKTER \\ AND MARIUM AKTER JHUMUR \\ Department of Fisheries Technology, Patuakhali Science and Technology University, \\ Dumki, Patuakhali 8602, Bangladesh \\ *Corresponding Author: sazedul.fst@pstu.ac.bd
}

\begin{abstract}
The study identified the quality differences of dried Chinese pomfret (Stromateus chinensis), Bombay duck (Harpodon nehereus) and ribbon fish (Trichiurus haumela) from market and drying center at Kuakata, Patuakhali. The sensory, nutritional and microbial quality of collected dried samples were evaluated following organoleptic quality index, standard AOAC and aerobic plate count methods, respectively. Organoleptically no significant difference found between the samples from market and drying center. The highest moisture content value was obtained in Bombay duck (29.78\%) from the market and lowest value in Chinese pomfret $(20.06 \%)$ from drying center. The highest and lowest protein content was in Chinese pomfret $(60.73 \%)$ and Bombay duck (47.9\%) from drying center and market, respectively. The lipid and ash content varied from $2.85 \%$ to $7.20 \%$ and $13.98 \%$ to $19.57 \%$ for all the dried fish species collected from both sites. Microbiologically, higher aerobic plate count (APC), total E. coli count (TEC) and total Salmonella count (TSC) were found in Chinese pomfret at $1.96 \times 10^{6} \mathrm{CFU} / \mathrm{g}, 3.98 \times 10^{5} \mathrm{CFU} / \mathrm{g}$ and $1.62 \times 10^{5} \mathrm{CFU} / \mathrm{g}$ from market and lowest count found in Bombay duck at $5.05 \times 10^{5}, 2.22 \times 10^{5}$ and $0.81 \times 10^{5}$ from drying center, respectively. In ribbon fish no Salmonella sp. was found. Based on the sensory and nutritional quality the study conclude that among three species and two sites studied, the dried Bombay duck from the fish drying center had better quality characteristics than the counter parts. However, higher microbial load especially pathogenic TSC and TEC suggests to improve hygiene and sanitary practices, better market distribution and storage facilities need to be followed by the producers for safe and quality dried fishery products.
\end{abstract}

Keywords: Dried fish, Fish drying center, Kuakata

\section{Introduction}

The dried fish and fishery products are widely regarded as a good source of protein and other essential nutrients for the maintenance of a healthy body (Arannilewa et al. 2005). These are generally processed traditionally at low-cost, easily transportable, marketable, storable (Nowsad 2007) and has good market demand. A sizeable quantity of fresh fish is preserved by sun drying in Bangladesh from freshwater as well as from marine fish. It is low cost dietary protein source and used as a substitute of fish at the scarcity of fresh fish in Bangladesh (Khan and Khan 2001). The southern region of Bangladesh is abundant in marine water fisheries resources. The amount of fish catches from fresh and marine water attains peak during winter season. As a result winter is considered to be the peak season for processing sun dried fish and continues till the onset of the rainy season. In the coastal villages, fish drying generally starts in October and ends in March (Nowsad 2007). A major problem associated with sun drying of fish in Bangladesh is the infestation of the product by fly and insect larvae during drying and storage. Dried fish contaminated by both insects and insecticides comprises about $60 \%$ of the total dried products and is considered to be unfit for human consumption (Nowsad 2005). Apart from these, other common sources of contamination are air and dust in and around fish processing place,

https://doi.org/10.52168/bjf.2021.33.16 
contaminated coastal water and soil and unhygienic handling (FAO 1982, Prabhakaran and Gupta 1990). There is a tendency of fishermen to dry whatever they catch. They are dried in open space on the sand, dykes or embankments, which are sources of bacterial contamination. Fatty species are very prone to oxidative rancidity even if drying is done very carefully.

The quality and safety of fish and fishery products have become a major concern worldwide (Huss et al. 2003). To consumers, the most important attributes of a food product are its sensory and nutritional characteristics. Bacterial contamination in food often results in food spoilage as well as life threatening health hazards like food poisoning (Prescott et al. 1999). Determination of microbiological count is widely used to assess the microbiological quality of dried fish. Determination of microbiological quality of such processed fishes is very important for guarding consumer's health and hygiene (Lilabati et al. 1999). Also the biochemical composition of dried fish is an important aspect in dried fish processing as it influences both the keeping quality and the physical characteristics of the dried fish. The microbial load affects the composition, freshness, spoilage and nutritional quality of the fish. The presence of pathogenic bacteria in dried fish is acquiring importance from the seafood safety and quality point of view (Patterson and Ranjitha 2009). Available reports suggest that the qualities of majority of the dried products and the consumers frequently complain about their quality. Therefore, this study aims to investigate the sensory, microbial and nutritional quality of dried fish available in drying center and market in Kuakata, Bangladesh.

\section{Materials and Methods}

Dried fish sample collection: Dried marine water fishes namely Chinese pomfret (Stromateus chinensis), Bombay duck (Harpodon nehereus) and ribbon fish (Trichiurus haumela) were collected from local market and drying centre of Kuakata during March 2018 to May 2019. Dried fish samples were packed tightly in polyethylene bags and transported to the Seafood Processing Safety and Quality laboratory of PSTU for subsequent studies.

Sensory assessment of dried fish: Sensory assessment was carried out on dried fish in the laboratory by using the Quality Index method to access the degree of freshness based on organoleptic characteristics such as color, odor, texture, flavor, insect infestation, general appearance and overall acceptability carried out on dried fish generally depends on the taste of panelists. Ten (10) panelists who had been selected and trained participated in the sensory evaluation. The qualities of the fishes were scored using the score from 1 to 5 according to scoring method (Table I and II). The score of average defect points less than 2 was A grade considered as excellent, highly acceptable, 2 to less than $4 \mathrm{~B}$ grade was judged as Good/acceptable, 4 or above $\mathrm{C}$ grade was considered as rejected. Numerical grading system was developed to evaluate the judgments or results, simply in the form of excellent/highly acceptable, acceptable/good, deteriorating/not acceptable and spoiled/rejected etc. in the quality index scheme for dried fish. The organoleptic characteristics of dried fish guidelines and methods were based on organoleptic method (Howgate et al. 1992) with some modification as in Table I and II. Organoleptic assessment was calculated by using following formula-

$$
\text { Average grade points }=\frac{\text { Total grade point }}{\text { Number of cherecteristics }}
$$


MST. NILOY JAMAN et al.

Table I. Organoleptic assessment of dried fish based on defect characteristics

\begin{tabular}{|c|c|c|c|c|c|c|}
\hline $\begin{array}{l}\text { Characteristics } \\
\text { of dried fish }\end{array}$ & Defect characters & $\begin{array}{c}\text { Defect } \\
\text { point }\end{array}$ & S-1 & $\mathrm{S}-2$ & $\mathrm{~S}-3$ & $\mathrm{~S}-4$ \\
\hline \multirow{5}{*}{ Color } & Whitish and shiny & 1 & & & & \\
\hline & Off white to yellowish & 2 & & & & \\
\hline & Shining yellowish to brownish & 3 & & & & \\
\hline & Brownish outer reddish in inner & 4 & & & & \\
\hline & Blackish to bleached & 5 & & & & \\
\hline \multirow{5}{*}{ Odor } & Natural dried fishy odor & 1 & & & & \\
\hline & Bland odor & 2 & & & & \\
\hline & Slightly to moderate fishy & 3 & & & & \\
\hline & Decomposed sour odor & 4 & & & & \\
\hline & Extremely decomposed sour and spoiled & 5 & & & & \\
\hline \multirow{5}{*}{ Texture } & Firm, tender and flexible & 1 & & & & \\
\hline & Slightly to moderate Soft & 2 & & & & \\
\hline & Extremely soft and slightly juicy & 3 & & & & \\
\hline & Brittle near to broken & 4 & & & & \\
\hline & Broken, juicy and skin raptured & 5 & & & & \\
\hline \multirow{3}{*}{ Flavor } & Natural and slight salty & 1 & & & & \\
\hline & Slight to moderate flavor & 2 & & & & \\
\hline & Strong and spoiled & 3 & & & & \\
\hline \multirow{3}{*}{ Insect Infestation } & No infestations & 1 & & & & \\
\hline & Slightly to moderate infestation & 2 & & & & \\
\hline & Completely infested by flies and insects & 3 & & & & \\
\hline \multirow{5}{*}{$\begin{array}{c}\text { General } \\
\text { appearance }\end{array}$} & Excellent & 1 & & & & \\
\hline & Good & 2 & & & & \\
\hline & Slight to moderate good & 3 & & & & \\
\hline & $\mathrm{Bad}$ & 4 & & & & \\
\hline & Very bad & 5 & & & & \\
\hline \multirow{5}{*}{$\begin{array}{c}\text { Over all } \\
\text { acceptability }\end{array}$} & Highly acceptable & 1 & & & & \\
\hline & Slight to moderate acceptable & 2 & & & & \\
\hline & Slightly Unacceptable & 3 & & & & \\
\hline & Very Unacceptable & 4 & & & & \\
\hline & Rejected & 5 & & & & \\
\hline \multicolumn{7}{|c|}{ Total defect point } \\
\hline & Average defect point & & & & & \\
\hline
\end{tabular}

Table II. Grading of dried fish acceptance

\begin{tabular}{c|c|c}
\hline Grade & Defect point & Degree of acceptance \\
\hline A & $<2$ & Excellent, Highly acceptable \\
\hline B & 2 to $<4$ & Good/ acceptable \\
\hline C & $4-5$ & Rejected \\
\hline
\end{tabular}


COMPARATIVE ASSESSMENT OF DRIED FISH QUALITY FROM KUAKATA IN PATUAKHALI

Microbial quality assessment of dried fish: For microbial studies Nutrient agar, Eosin Methylene Blue (EMB) agar, Xylose-Lysine Deoxycholate (XLD) agar media was prepared for Aerobic Plate count (APC), Total E. coli Count (TEC) and Total Salmonella sp. Count (TSC) respectively by the following manufacturer's instruction (Hi-media, India). The collected dried fish samples were chopped into small pieces. The preparation of collected dried fish samples and the bacterial culture were conducted following the standard method of Schulze-Schweifing et al. (2014). Briefly, 1-5 grams of dried fish sample were homogenized (BK-HG160, Biobase, China) and mixed in $200 \mathrm{ml}$ sterile phosphate-buffered saline (PBS, $10 \mathrm{mmol} / \mathrm{L} \mathrm{PO}_{4}{ }^{3-}, 137 \mathrm{mmol} / \mathrm{L}$ $\mathrm{NaCl}$, and $2.70 \mathrm{mmol} / \mathrm{L} \mathrm{KCl}, \mathrm{pH} 7.4)$ producing a $5 \%(\mathrm{~m} / \mathrm{v})$ sample suspension. The suspension was mixed thoroughly using a vortex mixture (VM-1000, DLII, Taiwan) before it was centrifuged (DM0412, DLAB-SI, USA). The supernatant was collected and was maintained as a stock solution.

Total microbial counts in dried fish sample: The stock solution (5\% suspension) was 10 fold serially-diluted up to $10^{-5}$ using $0.85 \%$ normal saline as diluent before $0.1 \mathrm{ml}$ of each of them was spread plated onto nutrient agar media. After an incubation at $37^{\circ} \mathrm{C}$ for 24 hours in the incubator (JSGI-10T, JSR, Korea), the colonies developed in the media were calculated and results were recorded as cfu/gm of dried fish sample using the following formula:

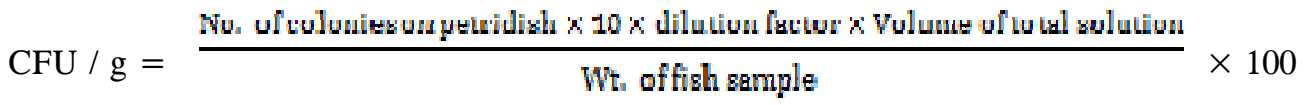

Microbial study on selective media: Aliquots of $0.1 \mathrm{ml}$ from each of the sample of dried fish after serial dilutions of their respective stock solutions were spread onto the selective media: EMB (Eosin methylene blue), and XLD (Xylose Lysine Deoxycholate), TCBS (Thiosulfatecitrate-bile salts-sucrose agar) agar for $E$. coli and Salmonella spp colonies development in the respective selective media. After an incubation at $37^{\circ} \mathrm{C}$ for 48 hours in the incubator (JSGI-10T, JSR, Korea) the developed colonies in the media were calculated and results were recorded as $\mathrm{cfu} / \mathrm{gm}$ of dried fish sample using the following formula:

$\mathrm{CFU} / \mathrm{g}=\frac{\text { No. of colonies on petridish } \times 10 \times \text { dilution factor } \times \text { Volume of total solution }}{\text { Wt. of fish sample }} \times 100$

Determination of proximate compositions: Moisture, protein, lipid, and ash were determined by using a hot air oven (Model DO-35, Human Instrument Co. Ltd, and Korea), Kjeldahl apparatus (Model Buchi CH-9230, Switzerland), Soxhlet apparatus (Model SRICO, SMX 100, behr LABORTECHNIK GmbH Co. Itd, Germany) and muffle furnace (Faithful, SX ceramic fiber muffle furnace, Huanghua Faithful Instrument Co. Ltd, China), respectively.

Statistical analysis of experimental data: The obtained data were analyzed to Mean \pm SD $(\mathrm{n}=3)$ using Microsoft Excel 2010 software. 


\section{Results and Discussion}

Sensory quality analysis of dried fish sample: The quality of dried fish products were assessed on the basis of color, odor, texture, insect infestation, presence of broken pieces and overall quality and then after considering their defect point, they were graded into $\mathrm{A}, \mathrm{B}$ and $\mathrm{C}$ which indicate excellent, highly acceptable, good/ acceptable and rejected quality, respectively. There was no significant difference in organoleptic characteristics among these samples collected from two sources (Table III). The dried Chinese pomfret, Bombay duck and ribbon fish exhibited yellowish to brownish, yellowish to light brownish and brownish color in outer and blackish color in inner, respectively.

The dried fish samples of Chinese pomfret and Bombay duck had moderate characteristic dry fish odor but in Ribbon fish decomposed sour odor was developed. Slightly to moderate soft texture was found in Chinese pomfret and Bombay duck and soft or damp texture was found in ribbon fish. Ribbon fish showed strong rancid flavor. Slightly to moderate infestation by flies and insects was observed among the samples. Considering their defect point and overall acceptability the samples were moderately good and acceptable. Previous study by Paul et al. (2018) shown that organoleptic characteristics in respect of color, odor, texture, insect infestation and presence of broken pieces in the products indicated poor to moderately acceptable condition. Jamil et al. (2017) found that organoleptically most of these sun-dried fishes were in "B" grade that means in "Good" condition (SDP 2.33 and 2.35 respectively). In another study Hossain et al. (2017) found that the color of sun-dried Silver pomfret from local market as slightly brown, some were brown to dark brown compared with freshly prepared samples having an attractive cream color. Slightly rancid odor and bitter taste was developed in some samples. Texture was hard but not firm in most of the samples. Overall sensory qualities of most of the samples were of "excellent grade", some were in "good grade". The color, odor, texture, insect infestation, presence of broken pieces of salt and turmeric treated dried ribbon fish was good (Imtiaz et al. 2017). Haque et al. (2013) observed that the color of collected traditional sun dried fish samples were ranged from silvery to white with wide variations in different species and that of all the products were characteristics with firm and flexible texture. 


\section{Table III. Organoleptic characteristics of dried fish from market and drying center in Kuakata}

\begin{tabular}{|c|c|c|c|c|c|c|c|c|c|c|c|}
\hline $\begin{array}{l}\text { Dried fish } \\
\text { sample }\end{array}$ & $\begin{array}{l}\text { Collection } \\
\text { source }\end{array}$ & Color & Odor & Texture & Flavor & $\begin{array}{c}\text { Insect } \\
\text { Infestation }\end{array}$ & $\begin{array}{c}\text { General } \\
\text { appearance }\end{array}$ & $\begin{array}{c}\text { Over all } \\
\text { acceptability }\end{array}$ & $\begin{array}{c}\text { Defect } \\
\text { point }\end{array}$ & Grade & $\begin{array}{c}\text { Grade } \\
\text { characteri } \\
\text { stics } \\
\end{array}$ \\
\hline $\begin{array}{l}\text { Chinese } \\
\text { pomfret }\end{array}$ & \multirow{3}{*}{ Market } & $\begin{array}{l}\text { Yellowish to } \\
\text { brownish in } \\
\text { color }\end{array}$ & $\begin{array}{l}\text { Slightly sour } \\
\text { odor }\end{array}$ & $\begin{array}{l}\text { Slightly } \\
\text { soft }\end{array}$ & $\begin{array}{l}\text { Slight to } \\
\text { moderate } \\
\text { flavor }\end{array}$ & $\begin{array}{c}\text { Slight } \\
\text { infestation }\end{array}$ & $\begin{array}{c}\text { Slight to } \\
\text { moderate good }\end{array}$ & $\begin{array}{l}\text { Slight to } \\
\text { moderate } \\
\text { acceptable }\end{array}$ & 3.07 & B & $\begin{array}{l}\text { Moderate } \\
\text { good and } \\
\text { acceptable }\end{array}$ \\
\hline Bombay duck & & $\begin{array}{c}\text { Yellowish to } \\
\text { brownish in } \\
\text { color }\end{array}$ & $\begin{array}{c}\text { Slightly to } \\
\text { moderate fishy }\end{array}$ & Slightly soft & $\begin{array}{l}\text { Slight to } \\
\text { moderate } \\
\text { flavor }\end{array}$ & $\begin{array}{c}\text { Slight } \\
\text { infestation }\end{array}$ & $\begin{array}{c}\text { Slight to } \\
\text { moderate good }\end{array}$ & $\begin{array}{c}\text { Slight to } \\
\text { moderate } \\
\text { acceptable }\end{array}$ & 2.89 & B & $\begin{array}{r}\text { Moderate } \\
\text { good and } \\
\text { acceptable }\end{array}$ \\
\hline Ribbon fish & & $\begin{array}{c}\text { Brownish in } \\
\text { outer and } \\
\text { blackish in inner }\end{array}$ & $\begin{array}{l}\text { Decomposed } \\
\text { sour odor }\end{array}$ & Soft or damp & Strong flavor & $\begin{array}{l}\text { Infested by } \\
\text { flies and } \\
\text { insects }\end{array}$ & $\begin{array}{l}\text { Slight to } \\
\text { moderate good }\end{array}$ & $\begin{array}{c}\text { Slight to } \\
\text { moderate } \\
\text { acceptable }\end{array}$ & 3.27 & B & $\begin{array}{r}\text { Moderate } \\
\text { good and } \\
\text { acceptable }\end{array}$ \\
\hline $\begin{array}{l}\text { Chinese } \\
\text { pomfret }\end{array}$ & \multirow{3}{*}{$\begin{array}{l}\text { Drying } \\
\text { centre }\end{array}$} & $\begin{array}{l}\text { Yellowish to } \\
\text { light brownish in } \\
\text { color }\end{array}$ & $\begin{array}{c}\text { Slightly to } \\
\text { moderate fishy }\end{array}$ & $\begin{array}{c}\text { Slight to } \\
\text { moderate soft }\end{array}$ & Slight flavor & $\begin{array}{c}\text { Slight } \\
\text { infestation }\end{array}$ & $\begin{array}{c}\text { Slight to } \\
\text { moderate good }\end{array}$ & $\begin{array}{c}\text { Slight to } \\
\text { moderate } \\
\text { acceptable }\end{array}$ & 3.01 & B & $\begin{array}{r}\text { Moderate } \\
\text { good and } \\
\text { acceptable }\end{array}$ \\
\hline Bombay duck & & $\begin{array}{l}\text { Brownish in } \\
\text { color }\end{array}$ & $\begin{array}{c}\text { Slightly to } \\
\text { moderate fishy }\end{array}$ & $\begin{array}{c}\text { Slight to } \\
\text { moderate soft }\end{array}$ & Slight flavor & $\begin{array}{c}\text { Slight } \\
\text { infestation }\end{array}$ & $\begin{array}{c}\text { Slight to } \\
\text { moderate good }\end{array}$ & $\begin{array}{c}\text { Slight to } \\
\text { moderate } \\
\text { acceptable }\end{array}$ & 2.78 & B & $\begin{array}{r}\text { Moderate } \\
\text { good and } \\
\text { acceptable }\end{array}$ \\
\hline Ribbon fish & & $\begin{array}{c}\text { Brownish in } \\
\text { outer and } \\
\text { blackish in inner }\end{array}$ & Sour odor & Soft or damp & Strong flavor & $\begin{array}{l}\text { Infested by } \\
\text { flies and } \\
\text { insects }\end{array}$ & $\begin{array}{c}\text { Slight to } \\
\text { moderate good }\end{array}$ & $\begin{array}{c}\text { Slight to } \\
\text { moderate } \\
\text { acceptable }\end{array}$ & 3.19 & B & $\begin{array}{r}\text { Moderate } \\
\text { good and } \\
\text { acceptable }\end{array}$ \\
\hline
\end{tabular}




\section{Microbiological analysis of dried fish sample}

Total bacterial load: The total aerobic plate count of Chinese pomfret, Bombay duck and ribbon fish from market was $1.96 \times 10^{6} \pm 2.27,6.01 \times 10^{5} \pm 1.68$ and $1.29 \times 10^{6} \pm 1.94 \mathrm{CFU} / \mathrm{g}$ respectively. On the other hand, total aerobic plate count of the represented sample collected from drying center was $1.27 \times 10^{6} \pm 1.16, \quad 5.05 \times 10^{5} \pm 1.62$ and $1.14 \times 10^{6} \pm 1.7 \mathrm{CFU} / \mathrm{g}$ respectively. The highest APC was found in the samples collected from market than drying center. The highest bacterial load was obtained in Chinese pomfret $1.96 \times 10^{6} \pm 2.27$ and lowest in Bombay duck $5.05 \times 10^{5} \pm 1.62 \mathrm{CFU} / \mathrm{g}$ (Table IV). It was observed that lowest bacterial load found in Bombay duck among three samples.

Table IV. Microbiological characteristics of dried fish from market and drying center, Kuakata

\begin{tabular}{|c|c|c|c|c|c|c|}
\hline \multirow{2}{*}{$\begin{array}{l}\text { Microbial } \\
\text { parameter } \\
(\mathrm{CFU} / \mathrm{g})\end{array}$} & \multicolumn{3}{|c|}{ Market } & \multicolumn{3}{|c|}{ Drying center } \\
\hline & $\begin{array}{l}\text { Chinese } \\
\text { pomfret }\end{array}$ & Bombay duck & Ribbon fish & $\begin{array}{l}\text { Chinese } \\
\text { pomfret }\end{array}$ & Bombay duck & Ribbon fish \\
\hline APC & $\begin{array}{c}1.96 \times 10^{6} \\
\pm 2.27\end{array}$ & $\begin{array}{c}6.01 \times 10^{5} \\
\pm 1.68\end{array}$ & $\begin{array}{c}1.29 \times 10^{6} \\
\pm 1.94\end{array}$ & $\begin{array}{c}1.27 \times 10^{6} \\
\pm 1.16\end{array}$ & $\begin{array}{c}5.05 \times 10^{5} \\
\pm 1.62\end{array}$ & $\begin{array}{c}1.14 \times 10^{6} \\
\pm 1.7\end{array}$ \\
\hline TEC & $\begin{array}{c}3.98 \times 10^{5} \\
\pm 0.88\end{array}$ & $\begin{array}{c}2.38 \times 10^{5} \\
\pm 0.61 \\
\end{array}$ & $\begin{array}{c}3.18 \times 10^{5} \\
\pm 0.74\end{array}$ & $\begin{array}{c}3.58 \times 10^{5} \\
\pm 0.81\end{array}$ & $\begin{array}{c}2.22 \times 10^{5} \\
\pm 0.36\end{array}$ & $\begin{array}{c}2.84 \times 10^{5} \\
\pm 0.30 \\
\end{array}$ \\
\hline TSC & $\begin{array}{c}1.62 \times 10^{5} \\
\pm 0.22\end{array}$ & $\begin{array}{c}1.04 \times 10^{5} \\
\pm 0.28\end{array}$ & Absent & $\begin{array}{c}1.61 \times 10^{5} \\
\pm 0.08 \\
\end{array}$ & $\begin{array}{c}0.81 \times 10^{5} \\
\pm 0.1\end{array}$ & Absent \\
\hline
\end{tabular}

APC, Aerobic plate count; TSC, Total Salmonella count; TEC, Total E. coli count.

The higher APC for traditional dried fish samples probably due to the fact that the higher moisture content and longer storage periods and poor hygienic condition during the preparation time. Drying by heat usually destroys all yeasts and most of the bacteria, but spores of some bacteria and molds usually survive. So, if the drying process and storage conditions are adequate, there will be no growth of microorganism in dried fish. But in traditional sun drying, it is about impossible to control moisture and growth of microbes during processing and storage of dried fish. Especially during improper storage and exposed condition in the retail market, dried products absorb a considerable amount of moisture and bacterial load found higher in market than drying center. The permissible limit of APC for cooked or dried fish is $1 \times 10^{5}$ $\mathrm{CFU} / \mathrm{g}$ at $37^{\circ} \mathrm{C}$ (Surendran et al. 2006). Here it was shown that, in case of three dried fish they exceed the permissible limit. Haque et al. (2013) found that in traditional sun dried fish sample the total aerobic bacterial count were in the range of $2.88 \times 10^{4}$ to $3.37 \times 10^{5} \mathrm{CFU} / \mathrm{g}$ for both Bombay duck and Silver pomfret collected from different region. Pravakar et al. (2013) observed the bacterial load of Chinese pomfret, Bombay duck and Ribbon dried products were $3.8 \times 10^{5}, 3 \times 10^{4}$ and $2.1 \times 10^{5} \mathrm{CFU} / \mathrm{g}$, respectively with lowest value in Bombay duck and highest value in Chinese pomfret.

Identification of Salmonella and $E$. coli isolated from dried fish samples: The samples collected from market found total Salmonella $s p$ in Chinese pomfret was $1.62 \times 10^{5} \pm 0.22 \mathrm{CFU} / \mathrm{g}$ and in Bombay duck $1.04 \times 10^{5} \pm 0.28 \mathrm{CFU} / \mathrm{g}$ (Table IV). The samples from drying centre found total Salmonella $s p$ in Chinese pomfret was $1.61 \times 10^{5} \pm .08 \mathrm{CFU} / \mathrm{g}$ and in Bombay duck $0.81 \mathrm{x}$ $10^{5} \pm 0.1 \mathrm{CFU} / \mathrm{g}$. On the other hand in Ribbon fish Salmonella $s p$ was absent both in market and drying centre. The total $E$ coli found in Chinese pomfret, Bombay duck and Ribbon fish was $3.98 \times 10^{5} \pm 0.88 \mathrm{CFU} / \mathrm{g}, 2.38 \times 10^{5} \pm 0.61 \mathrm{CFU} / \mathrm{g}$ and $3.18 \times 10^{5} \pm 0.74 \mathrm{CFU} / \mathrm{g}$ respectively in 
market and in drying center $3.58 \times 10^{5} \pm 0.81 \mathrm{CFU} / \mathrm{g}, 2.22 \times 10^{5} \pm 0.36 \mathrm{CFU} / \mathrm{g}$ and $2.84 \times 10^{5}$ $\mathrm{CFU} / \mathrm{g}$ respectively. Highest $E$ coli found in market Chinese pomfret $3.98 \times 10^{5} \pm 0.88 \mathrm{CFU} / \mathrm{g}$ and lowest found in drying center Bombay duck $2.22 \times 10^{5} \mathrm{CFU} / \mathrm{g}$. Among both place highest $E$ coli was found in samples from market than drying center. The permissible limit of TSC for cooked or dried fish is $1 \times 10^{5} \mathrm{CFU} / \mathrm{g}$ at $37^{\circ} \mathrm{C}$ (Surendran et al. 2006). Good quality dried fish should be totally free from Salmonella spp. However, in the current study both market and drying yard sources dried fish had higher Salmonella spp content in Chinese pomfret, which is highly health and food safety concern. The higher TSC and TEC content might due to contaminated/polluted water used, poor sanitary condition and unhygienic handling practice applied during preparation of dried fish in the study site. Other studies also reported that incidence of Salmonella spp. in the traditional dried fish may be attributed to external contamination such as polluted water, sand and unclean place used for drying and poor handling at ambient temperature. Contamination of fish and fishery products with Salmonella and Shigella has been reported by many researchers (Sinduja et al. 2011). Logesh et al. (2012) revealed that among the coliforms, E. coli were dominant followed by Vibrio sp., Salmonella sp. and Staphylococcus sp., respectively.

Proximate analysis of dried fish sample: The Moisture content of dried Chinese pomfret, Bombay duck and Ribbon fish were $25.13 \pm 1.4 \%, 29.78 \pm 1.07 \%$, and $28.33 \pm 0.7 \%$ respectively in market and in drying center $20.06 \pm 0.37 \%, 27.04 \pm 0.8 \%$ and $23.58 \pm 0.71 \%$ respectively. The highest moisture value was found in Bombay duck in market and lowest value in Chinese pomfret in drying center. The protein content found in market were $54.24 \pm 1.33 \%$, $47.9 \pm 1.32 \%, 51.13 \pm 0.7 \%$ and in drying center $60.73 \pm 0.86 \%, 50.63 \pm 0.38 \%$ and $55.31 \pm 0.69 \%$ respectively. Highest value found in Chinese pomfret $60.73 \pm 0.86 \%$ in drying center and lowest in Bombay duck $47.9 \pm 1.32 \%$ in market (Table V).

Table V. Proximate composition analysis of dried fish from market and drying center, Kuakata

\begin{tabular}{|c|c|c|c|c|c|c|}
\hline \multirow{2}{*}{$\begin{array}{c}\text { Proximate } \\
\text { Composition } \\
\%\end{array}$} & \multicolumn{3}{|c|}{ Market } & \multicolumn{3}{|c|}{ Drying center } \\
\hline & $\begin{array}{l}\text { Chinese } \\
\text { pomfret }\end{array}$ & Bombay duck & Ribbon fish & $\begin{array}{l}\text { Chinese } \\
\text { pomfret }\end{array}$ & Bombay duck & Ribbon fish \\
\hline Moisture & $25.13 \pm 1.4$ & $29.78 \pm 1.07$ & $28.33 \pm 0.7$ & $20.06 \pm 0.37$ & $27.04 \pm 0.8$ & $23.58 \pm 0.71$ \\
\hline Ash & $16.25 \pm 0.01$ & $19.57 \pm 0.7$ & $16.25 \pm 0.67$ & $15.04 \pm 0.45$ & $19.12 \pm 0.71$ & $13.98 \pm 0.83$ \\
\hline Protein & $54.24 \pm 1.33$ & $47.9 \pm 1.32$ & $51.13 \pm 0.7$ & $60.73 \pm 0.86$ & $50.63 \pm 0.38$ & $55.31 \pm 0.69$ \\
\hline Lipid & $3.58 \pm 0.23$ & $2.85 \pm 0.41$ & $5.26 \pm 0.4$ & $4.17 \pm 0.5$ & $3.92 \pm 0.61$ & $7.20 \pm 0.41$ \\
\hline
\end{tabular}

The lipid content found in market and drying center were $3.58 \% \pm 0.23,2.85 \% \pm 0.41$, $5.26 \% \pm 0.4$ and $4.17 \% \pm 0.5,3.92 \% \pm 0.61$ and $7.20 \% \pm 0.41$ respectively. Where highest lipid content $7.20 \pm 0.41 \%$ found in Ribbon fish in drying center and lowest in Bombay duck $2.85 \pm 0.41 \%$ in market. On the other hand, the ash content found in market and drying center were $16.25 \% \pm 0.01,19.57 \% \pm 0.7,16.25 \% \pm 0.67$ and $15.04 \% \pm 0.45,19.12 \% \pm 0.71$ and $13.98 \% \pm 0.83$ where highest ash content $19.57 \pm 0.7 \%$ found in Bombay duck in market and lowest in drying center Ribbon fish $13.98 \pm 0.83 \%$ (Table V). The study of Hossain et al. (2017) found that moisture content (\%) of sun-dried in Silver Pomfret and Perch was 39.59 \pm 0.34 $26.74 \pm 0.47$, respectively. The finding of Hoque et al. (2018) observed that the moisture content of improved traditional dryer dried fish products ranged from $16.71 \%$ to $21.1 \%$. The study of Hossain et al. (2017) found crude protein content (\%) of Silver Pomfret and Perch at 
$32.25 \pm 1.50$, and $40.31 \pm 2.13$, respectively which was less similar to present findings. In other study similar findings of protein contents on wet weight ranged from $55.2 \%$ to $60.16 \%$ in case of improved traditional dryer dried Silver pomfret, Bombay duck and Ribbon fish observed by (Hoque et al. 2018). However, the findings of this study showed that the average protein level obtained from dried fishes were very close with the previous studies. The present study agreed with Hossain et al. (2017) lipid content (\%) of sun-dried Silver Pomfret and Perch was $7.75 \pm 0.20$ and $5.03 \pm 0.55 \%$, respectively. Hoque et al. (2018) found that the lipid contents on wet weight basis for the products $12.9 \%$ to $18.80 \%$ respectively.

The present findings supported the findings of Haque et al. (2013) observed that the range of ash content of traditional sun dried Silver pomfret and Bombay duck was $16.95 \%$ to $21.41 \%$, respectively. In another study Jamil et al. (2017) found that the ash content of sun dried Bombay duck and Ribbon fish was $16.22 \pm 0.56 \%, 12.33 \pm 0.27 \%$ respectively. The study of Hossain et al. (2017) found ash content (\%) of Silver Pomfret and Perch at 15.75 \pm 0.39 and $11.50 \pm 0.26$, respectively. In another study Hoque et al. (2018) found that the ash contents of the dryer were $5.18 \%$ to $7.5 \%$ respectively. Organoleptically dried fish samples collected from market and drying center were same quality, where between the species Bombay duck was better than Chinese pomfret, and Ribbon fish. Nutritionally, the highest protein $60.73 \%$ (Chinese pomfret) and lipid $7.20 \%$ (Ribbon fish) content in samples from drying center. The highest bacterial load was found in the Chinese pomfret from market and lowest in Bombay duck from drying center. Presences of Salmonella sp. and E.coli made the dried fish (except dried ribbon fish) poor quality, represent the poor hygienic and sanitation practices by the producers. Considering the any quality aspects, dried fish from drying center was better than market place. Microbiologically, all the dried fish samples from market and drying center exceed the recommended permissible limit where identified pathogenic microbes are highly food safety and public health concern.

Acknowledgments: The authors would like to acknowledge to the Research and Training Center of Patuakhali Science and Technology University for the financial support (2018-19) for this research.

\section{Literature Cited}

Arannilewa, S.T., S.O. Salawu, A.A. Sorungbe and B.B. Ola-Salawu, 2005. Effect of frozen period on the chemical, microbiological and sensory quality of frozen tilapia fish (Sarotherodun galiaenus). Afr. J. Biotechnol., 4: 852-855.

FAO, 1982. Food and Agriculture Organization of Rome. Manual to codes of practices for fish and fishery products.

Haque, E., M. Kamruzzaman, M.S. Islam, T. Sarwar, S.S. Rahman and M.R. Karim, 2013. Assessment and comparison of quality of solar tunnel dried Bombay duck and Silver pomfret with traditional sun dried samples. Int. J. Nutr. Food Sci., 2: 187-195.

Hoque, M.M., A. Rayhan, K.B. Uddin, and S.K. Sarker, 2018. Qualitative assessment of improved traditional fish drying practices in Cox's Bazar. Int. J. Nat. Soc. Sc. 5(3): 30-36.

Hossain, M.N., M.G.M. Jamil, M.M. Mia, M.N. Uddin and M.A. Mansur, 2017. Studies on the proximate composition, quality and heavy metal concentration of two sun dried marine fish (SunDried Silver Pomfret and Sun-Dried Perch) of Cox 's Bazar District of Bangladesh. J. Environ. Sci. Nat. Resour., 10: 25-32. 
Howgate, P.A., P. Johnson and K.J. Whittle, 1992. Multilingual Guide to EC freshness grades for fishery products. Torry Research Station, Aberdeen. Food Safety Directorate, Ministry of Agriculture, Fisheries and Food, UK, 9p.

Huss, H.H., L. Ababouch and L. Gram, 2003. Assessment and Management of Seafood Safety and Quality. pp: 239. Food and Agriculture Organization of the United Nations. Rome. FAO, Fisheries Technical Paper, 444p.

Imtiaz, M.M., S.A. Haque, M.R. Sarker, M.M. Mufty, M.M. Ali, M.S. Parvez, M.S. Reza, M.S. Bhuyan, and M.A. Rahman, 2017: Quality assessment of improved sun dried ribbon fish (Trichiurus haumela) by salt and turmeric powder treatment. Int. J. Adv. Chem. Eng. Biol. Sci., 4(1): 162-167.

Jamil, M.G.M., M.N. Hossain, M.M. Mia, M.A. Mansur and S. Uga, 2017. Studies on the proximate composition, quality and heavy metal concentration of sundried Bombay duck and sun-dried ribbon fish of Cox's Bazar District of Bangladesh. J. Environ. Sci. Nat. Resour., 10(1): 55-60.

Kasozi, N., V.T. Namulawa, G.I. Degu, C.D. Kato and J. Mukalazi, 2016. Bacteriological and physicochemical qualities of traditionally dry-salted Pebbly fish (Alestes baremoze) sold in different markets of West Nile Region, Uganda. Afr. J. Microbiol. Res., 10: 1024-1030.

Khan, M.A.A. and Y.S.A. Khan, 2001. Insect's infestation and preventive measures in dry fish storage of Chittagong, Bangladesh. J. Biol. Sci., 1: 963-965.

Lilabati, H., W. Vishwanath and M. Singh, 1999. Changes in bacterial and fungal quality during storage, Esomus danricus of Manipur. Fish. Technol., 36: 36 - 39.

Logesh, A.R., M. Pravinkumar, S.M. Raffi and M. Kalaiselvam, 2012. An investigation on microbial screening on salt dried marine fishes. J. Food Res. Sci., 1: $15-21$.

Nowsad, A.K.M.A., 2005. Low-cost Processing of Fish in Coastal Bangladesh. BGD/97/017 Field Doc: 05/2005. Food and Agriculture Organization of the United Nations. Dhaka. 73p.

Nowsad, A.K.M.A., 2007. Participatory Training of Trainers: A New Approach Applied in Fish Processing. Bangladesh Fisheries Research Forum. 329p.

Patterson, J. and G. Ranjitha, 2009. Qualities of commercially and experimentally sun dried fin fish, Scomberoides tol. Afr. J. Food Sci., 3: 299-302.

Paul, C.P., S.M. Reza, M.N. Islam and M. Kamal, 2018. Quality assessment of traditionally dried marine fish of Bangladesh. Asian Food Sci. J., 5(1): 1-11.

Prabhakaran, N. and R. Gupta, 1990. Handling, processing and marketing of tropical fish. Fish. Technol., 27: 66-69.

Prescott, L.M., J.P. Harry and D.A. Klein, 1999. Food and Industrial Microbiology: Chapter 43, 4th Edition, Mc Graw Hill publication, New York.

Schulze-Schweifing, K., A. Banerjee and W.G. Wade, 2014. Comparison of bacterial culture and 16S rRNA community profiling by clonal analysis and pyrosequencing for the characterization of the dentine caries-associated microbiome. Front Cell Infect Microbiol, 4: 164.

Sinduja, P.P., J.K. Immaculate, C.G. Reiba and J. Patterson, 2011. Microbial quality of salted and sun dried sea foods of Tuticorin dry fish market, Southeast coast of India. Int. J. Microbiol. Res., 2: 188 $-195$.

Surendran, P., K.N. Thampuran, V. Narayanannambiar and K.V. Lalitha, 2006. Laboratory manual on microbiological examination of seafood, pp: 28-45. 